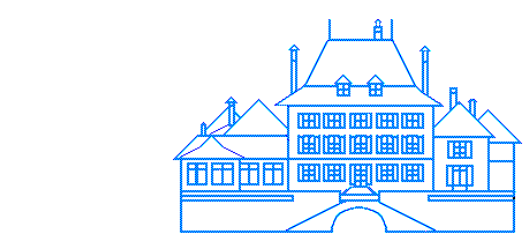

STUDIENZENTRUM GERZENSEE

STIFTUNG DER SCHWEIZERISCHEN NATIONALBANK

\title{
Tax Collection Costs, Tax Evasion and Optimal Interest Rates
}

\author{
A. Pınar Yeşin
}

Working Paper 04.02

This discussion paper series represents research work-in-progress and is distributed with the intention to foster discussion. The views herein solely represent those of the authors. No research paper in this series implies agreement by the Study Center Gerzensee and the Swiss National Bank, nor does it imply the policy views, nor potential policy of those institutions. 


\title{
Tax Collection Costs, Tax Evasion and Optimal Interest Rates*
}

\author{
A. Pınar Yeşin ${ }^{\dagger}$ \\ Study Center Gerzensee, P.O.Box 21, 3115 Gerzensee, Switzerland
}

April 2004

\begin{abstract}
In this paper, I investigate to what extent the cross-country variation in nominal interest rates can be explained as being due to governments' optimal response to economic conditions such as tax collection costs, tax evasion and government consumption needs. In particular, I study the effects of costly income taxes in the presence of an informal sector on the solution to a Ramsey problem in a general equilibrium framework. Unlike most of the previous analyses of optimal inflationary finance, the model postulates that conventional taxes carry collection costs whereas fiat money can be printed costlessly. For some countries, I measure tax collection costs, use the tax evasion estimates reported in the literature, and then calculate the optimal interest rate based on the model. Comparison of the actual and optimal interest rates demonstrates that the model can in fact partly explain the observed deviations from the Friedman Rule. I also show that allowing cross-country differences in the elasticity of substitution between formal and informal sectors can increase the model's explanatory power.
\end{abstract}

JEL Classification Numbers: E31, H21, H26, O17

Keywords: Optimal Interest Rates, Tax Collection Costs, Tax Evasion, Friedman Rule.

*This paper is based on chapter 2 of my doctoral thesis submitted to the University of Minnesota. It previously circulated under the title "Tax Collection Costs, the Informal Sector and Optimal Interest Rates". I am grateful to my adviser Narayana Kocherlakota for his invaluable guidance and continuing support. Many thanks also go to Philippe Bacchetta, Michele Boldrin, V.V. Chari, Larry Jones and Ross Levine for their useful comments. I have benefited from discussions with Kemal Badur, Guilherme Carmona, and with the seminar participants of the Applied Economics Workshop at the University of Minnesota, of the Research Seminar at the Swiss National Bank and of the Macroeconomics Workshop at the University of Lausanne. Any remaining errors are my own.

${ }^{\dagger}$ E-mail: Pinar.Yesin@szgerzensee.ch. Tel.: + 41-31-780-3203. Fax: + 41-31-780-3100. 


\section{Introduction}

There has been a huge variation in nominal interest rates, inflation rates and seigniorage revenues across countries. In this paper, I attempt to systematically account for these cross-country differences in long-run monetary policy. In particular, I investigate to what extent the variation in nominal interest rates can be attributed to governments' optimal response to economic conditions such as tax collection costs, presence of an informal sector and government consumption needs.

Using a simple cash-credit model in a dynamic general equilibrium framework, I study the effects of tax collection costs in the presence of an informal sector on the solution to a Ramsey problem. Then, for a variety of countries I measure tax collection costs and calculate the optimal interest rate implied by the model. I find that even though substantial deviations from the Friedman Rule are justified in an economy with a costly tax collection system and tax evasion, the model fails to explain the whole variation in nominal interest rates across countries.

As Keynes (1924) puts it, inflationary finance "is the form of taxation which the public find hardest to evade and even the weakest government can enforce, when it can enforce nothing else." Table 1 demonstrates that inflationary finance has been widely used around the world during the last quarter of the 20th century. Theoretically, however, Friedman (1969) shows that only monetary policies that generate a zero net nominal interest rate will yield to optimal resource allocation in the economy. This "Ramsey problem" result has been proven to be robust for a wide range of dynamic monetary general equilibrium models with income or consumption taxes. The findings are summarized in Correia and Teles (1999), Chari, Christiano, and Kehoe (1996), and Chari and Kehoe (1999), among others.

I extend the cash-credit model used in Chari and Kehoe (1999) to incorporate two potentially very important issues in optimal monetary and fiscal policy: tax collection costs and tax evasion. Then I derive the relationship between these two factors and optimal interest rate. The questions why there is an informal sector present in the economy and why some tax systems are more inefficient than others are outside the scope of this paper. Taking these 
two factors already as given in the economy I consider the optimal combination of inflation and conventional taxes ${ }^{1}$.

Unlike most of the previous analyses of optimal inflationary policy, the model described here postulates that conventional taxes, and specifically income taxes, carry collection costs whereas fiat money can be printed costlessly. The idea behind this assumption is that the government has to spend some resources to change and implement tax laws, audit claims, enforce tax filing and so on. However, fiat money can be printed almost costlessly ${ }^{2}$. A linear tax collection cost function is assumed throughout this paper both for simplicity of analysis and because the US time series data of tax collection costs does not suggest otherwise.

In addition, I assume that there is an informal sector ${ }^{3}$ present in the economy contributing to economic activity but not paying income taxes. This sector generally consists of unregistered companies and small businesses that are usually owner-operated and that typically do not engage in illegal activities; they are just not regulated or taxed by the government ${ }^{4}$.

In a small open economy shopping-time framework, Végh (1989) finds that the optimal inflation tax becomes an increasing function of government spending only when consumption taxes carry increasing marginal collection costs. He also shows that the optimal inflation

\footnotetext{
${ }^{1}$ One of the reasons for inefficiency in tax collection might be that in some countries a large proportion of output is produced by a large number of small, owner-run firms and that it is very costly to the government to enforce taxes on them. These countries happen to be mainly developing high inflation countries, whereas in other - mostly developed - countries, output is mainly attributable by a relatively small number of big firms. The managers of these big firms have to keep accurate financial records to attract shareholders, and the government can check those records without incurring high costs. Analyzing the link between tax collection and distribution of companies by size could be a topic for further research.

${ }^{2}$ Banknote printing costs may be considered as an item of government consumption, since supplying the medium of exchange to the public is a service provided by the government. Nonetheless, to have an exact comparison of tax collection costs versus money printing costs, in the US during fiscal year 1999 it cost 0.43 cents to collect 1 dollar in tax revenue whereas it cost only 0.022 cents to increase the money supply by 1 dollar.

${ }^{3}$ In the literature, the informal sector has also been called the underground sector, shadow economy, or black market.

${ }^{4}$ Based on IRS statistics, Witte (1987) estimates that only $10 \%$ of the informal sector is engaged in illegal activities in the US.
} 
tax does not depend on the level of government spending in the case of constant marginal costs. However, the Ramsey problem in the paper lacks the implementability constraint and therefore the results are not comparable. In this paper, I show that even a constant marginal cost yields a positive relationship between the size of the government and the optimal interest rate. One of the findings is that as government expenditures increase, the optimal interest rate increases as well.

So far, three papers have explored the presence of an informal sector in a dynamic monetary general equilibrium model. They all show that the Friedman Rule ceases to be optimal once the informal sector is introduced in a Ramsey Problem. The first one of these papers is Nicolini (1998). In a cash-credit economy with a continuum of consumption goods he shows that the optimal net interest rate is strictly positive when there is an informal sector in the economy that cannot be taxed by the government. However, empirically he finds that his model can only account for a very small portion of observed inflation rates even in countries with very large underground sectors, such as Peru. This leads him to conclude that the presence of an informal sector cannot explain the high inflation rates observed around the world.

In the second paper Cavalcanti and Villamil (2003) assume the presence of a similar informal sector in the economy. Using different monetary models, they show that the Friedman Rule is not optimal. Using the U.S. economy as a baseline they find that for alternative calibrations the annual inflation tax can range from $0 \%$ to $22 \%$. They also provide a welfare analysis of reducing inflation.

Finally, in the third paper, Koreshkova (2001) uses a shopping time model with a continuum of markets in the economy, and shows that high inflation can be a result of optimal financing of a government budget in the presence of the informal sector as well. However, she does not provide a numerical comparison between her model's implications and observed inflation rates.

In a related essay, de Fiore (2000) uses a shopping time model and shows that there are conditions under which the Friedman Rule is still optimal despite the presence of tax collection costs. Then she computes that the optimal annual nominal interest rate for the US 
economy to be less than $1 \%$ even when tax collection generates losses as high as $20 \%$ of the revenues. Thus she concludes that tax collection costs cannot justify substantial deviations from the Friedman Rule.

The present paper is different from all of the above mentioned papers because it systematically accounts for the cross-country differences in monetary policy. I also model tax collection costs and the presence of an informal sector simultaneously and estimate tax collection costs for a variety of countries. Finally, I calculate steady state Ramsey interest rates and compare them with 25-year averages.

I also have to stress that the purpose of this paper is not to explain the variation in interest rates across time in a given economy. It is rather to gauge the explanatory power of tax collection costs and presence of an informal sector for long-run deviations from the Friedman Rule across countries.

I show that the optimal interest rate increases with the inefficiency of the tax system, with the size of the informal sector and with the size of the government. A noteworthy policy implication is that it is very crucial for the governments to have an efficient tax collection system and to decrease the size of the informal sector in order not to have to rely on inflationary finance.

The optimal net annual nominal interest rate for the U.S. is estimated to be $8.12 \%$. This corresponds to annual inflation of $3.86 \%$. When I compute the optimal interest rate for the other countries in the sample, I find that for some of the countries the implied interest rates are in fact very close to the observed ones. Particularly for the small group of countries for which tax collection costs could be directly estimated, the model performs fairly well. Nonetheless, the model overestimates the interest rate for the Asian countries, and underestimates it for the Latin American countries. The elasticity of substitution between formal and informal sectors turns out to be a crucial parameter to which the optimal interest rate is quite sensitive. Since cross-country estimates of this parameter are not available in the literature I use the benchmark value for each country. However, it might be possible that, for example, the Latin American countries have a higher elasticity of substitution between these two sectors, and that the optimal interest rates are therefore higher than my estimates 
based on the benchmark value. In that case the model would indeed predict interest rates closer to the actual ones for those countries as well.

Using the available data, however, the model cannot explain the whole cross-country variation in interest rates. I conclude that optimality considerations seem to account for only a small fraction of the variation in nominal interest rates for some countries. Other factors, such as politico-economic ones, may be more responsible for the cross-country variation in monetary policy.

This paper is organized as follows: In Section 2, I present cross-country data on tax collection cost and the informal sector. Section 3 explains the model, Section 4 states the Ramsey problem and Section 5 gives the quantitative results. Section 6 concludes with policy implications. The proof of the main proposition is given in the appendix.

\section{Nominal Interest Rates, Tax Collection Costs, the Informal Sector and Government Expenditures}

In the literature it has been documented that for most countries, seigniorage revenue is not the primary source of revenue for the government, but neither is it quantitatively insignificant (see Click (1998) and Cukierman, Edwards, and Tabelini (1992) for example). Table 1 lists 25-year averages of annual nominal interest rates and seigniorage revenues for 23 countries. Average annual interest rates vary from about 3\% in Switzerland to 113\% in Israel. Average seigniorage revenue - defined as the share of new printed money in nominal government expenditures — varies from 1.03\% in Sweden to 29.29\% in Peru; average seigniorage revenue - defined as the share of new printed money in nominal formal output — varies from $0.19 \%$ in Switzerland to $11.62 \%$ in Israel.

There are two aspects of the deadweight loss associated with tax collection: tax collection costs incurred by the government and tax compliance costs borne by the taxpayers. In this paper, the burden on the taxpayers is ignored since it is very difficult - and sometimes impossible - to obtain estimates on tax compliance numbers, and focus on the tax 
collection costs incurred by the government. Still, one should keep in mind that this paper's implications would be reinforced if the compliance costs were included in the model and in the estimations ${ }^{5}$.

I approximate tax collection costs incurred by a government as the ratio of the tax collection agency's budget to total tax revenue. Tax collection costs for the US between years 1976 and 2000 are given in Table 2. Even though the numbers in the fourth column are small, they are persistently different from zero. On average, it cost 50 cents to raise 100 dollars tax revenue in the US during the period 1976-2000.

The data on total tax revenue and the budget of the tax collection agency for a selection of countries is given in Table 3. The efficiency of the tax collection system is defined as one minus the unit tax collection cost. The closer this parameter is to one, the fewer resources are wasted during the tax collection process; hence a higher fraction of the tax revenue can be used to finance the government spending. According to the available data, the US seems to be the most efficient country in tax collection whereas Turkey is the least efficient among the countries listed.

On the other hand, the size of the informal sector is generally expressed as the ratio of output produced by the informal sector to the output produced by the formal sector. There are two broad approaches used in the literature for estimation: Surveys and tax audits are examples of the direct approach; currency demand method, physical input (electricity consumption) method, and Multiple Indicators Multiple Causes Model are examples of the indirect approach. Applying some of these methods, Schneider and Enste (2000) estimate the size of the informal sector for a variety of countries and Öğ̈̈nç and Yılmaz (2000) for Turkey during 1990s. In my estimation of optimal interest rates, I rely on the numbers that these papers provide.

\footnotetext{
${ }^{5}$ Especially in the United States, the current income tax system is very complicated. For example, the Internal Revenue Services estimated that the public spent nearly 6 billion hours in year 2000 on compliance activities, such as record keeping, tax planning, form completion and form submission. Although the tax systems in other countries are not as complicated as in the U.S., there are still tax compliance costs for the consumers.
} 
The size of the government is also usually expressed as the share of government consumption expenditures in total formal output. Table 4 gives data on the size of the government and the size of the informal sector for the same group of countries as in Table 1.

Excluding Israel, the interest rates seem to decrease with the size of the government. However, after inclusion of Israel the relationship disappears. Figure 1 shows this finding ${ }^{6}$.

The positive relationship between the interest rates and the size of the informal sector is shown in Figure 2. Less developed countries with a large informal sector - and probably with less effective tax systems as well as large and pressing revenue needs - seem to use the inflation tax more intensively. The midpoint of the range reported in Table 4 was used as a proxy for the size of the informal sector in this graph and later in the quantitative results section.

\section{Model}

This is a version of the cash-credit model of Lucas and Stokey (1983) with costly income taxes and an informal sector. This simple cash-credit model is chosen in order to make the results comparable with the existing literature, e.g. Chari and Kehoe (1999).

There is a large number of identical infinitely lived consumers in the economy and time is discrete. There are two types of goods: cash and credit goods. Cash goods can only be bought with cash. Other than the payment technology used there is no difference between these two types of goods.

The preferences of a representative agent can be represented by a discounted lifetime utility function

$$
\sum_{t=0}^{\infty} \beta^{t} U\left(c_{1}(t), c_{2}(t), h(t)\right)
$$

where $c_{1}$ denotes private consumption of the cash good, $c_{2}$ denotes private consumption of the credit good and $h$ denotes leisure. The utility function is assumed to satisfy the INADA conditions and has the usual concavity and monotonicity properties.

\footnotetext{
${ }^{6}$ Country codes are as in Heston et al. (2002) data set — ISO-136 classification system.
} 
In this economy there are two types of firms: firms registered with the government that pay taxes, i.e. the formal sector, and firms not registered with the government that evade taxes, i.e. the informal sector, which together produce a final consumption good. Thus the final consumption good is assumed to be a composite of goods supplied by both the formal and informal sectors. I assume that the total output produced by the formal and informal sectors is given by a constant returns to scale production function

$$
Y\left(l_{F}(t), l_{I}(t)\right)
$$

where $l_{F}$ and $l_{I}$ are labor supplied by the representative agent to the formal and informal sectors, respectively.

Workers are paid their marginal products in both sectors:

$$
w_{F}(t)=\frac{\partial Y\left(l_{F}(t), l_{I}(t)\right)}{\partial l_{F}(t)}=Y_{l_{F}}(t) \quad \text { and } \quad w_{I}(t)=\frac{\partial Y\left(l_{F}(t), l_{I}(t)\right)}{\partial l_{I}(t)}=Y_{l_{I}}(t)
$$

Each period the representative consumer supplies his labor to the registered and unregistered firms, pays taxes on labor income received from the registered firms, receives his return on bonds acquired previously, faces a cash-in-advance constraint for the cash good, consumes cash and credit goods, and then acquires new bonds and new cash for the next period with his remaining income.

Therefore the consumer's problem can be written as

$$
\begin{array}{ll}
\max & \sum_{t} \beta^{t} U\left(c_{1}(t), c_{2}(t), h(t)\right) \\
\text { s.t. } & M(t+1)+B(t+1)+p(t) c_{1}(t)+p(t) c_{2}(t)=R(t) B(t)+M(t)+p(t) l_{I}(t) w_{I}(t) \\
& \quad+p(t)[1-\tau(t)] l_{F}(t) w_{F}(t) \\
& p(t) c_{1}(t) \leq M(t) \\
& h(t)=1-l_{F}(t)-l_{I}(t) \\
& -B \leq \frac{B(t)}{p(t)} \leq B \\
& M(t), c_{1}(t), c_{2}(t), l_{F}(t), l_{I}(t), h(t) \geq 0
\end{array}
$$

where $R(t)$ is the gross interest rate paid on nominal bonds, $B(t)$, acquired last period, $M(t)$ is the money holdings, $p(t)$ is the price level in the economy, and $\tau(t)$ is the tax rate on 
formal labor income. The first constraint is the budget constraint; note that the consumer only pays taxes on his income from the formal sector. The second constraint is the cash in advance constraint for the cash good, the third one guarantees that total time spent on work and leisure is equal to 1 , and the fourth one lets the holdings of real debt be bounded from above and below to rule out Ponzi schemes.

The government finances its expenditures through printing new money, issuing new bonds and collecting labor income taxes from registered firms. However, the government must incur certain costs while collecting taxes.

For simplicity of analysis, the tax collection cost function is assumed to be linear in tax reveneu. Total cost incurred by the government when collecting $\tau(t) l_{F}(t) w_{F}(t)$ is given by

$$
\phi\left(\tau(t) l_{F}(t) w_{F}(t)\right)=(1-\kappa) \tau(t) l_{F}(t) w_{F}(t)
$$

where $0 \leq \kappa \leq 1$ denotes the efficiency of the tax system ${ }^{7}$. Therefore, the government's period budget constraint is

$$
\begin{array}{r}
R(t) B(t)+p(t) g(t)+p(t)(1-\kappa) \tau(t) l_{F}(t) w_{F}(t)=M(t+1)-M(t)+B(t+1) \\
+p(t) \tau(t) l_{F}(t) w_{F}(t)
\end{array}
$$

where $g(t)$ is a given stream of government consumption expenditures.

The resource constraint in this economy is

$$
c_{1}(t)+c_{2}(t)+g(t)+(1-\kappa) \tau(t) l_{F}(t) w_{F}(t)=Y\left(l_{F}(t), l_{I}(t)\right)
$$

The last term on the left hand side signifies the resources used up during tax collection.

An allocation is denoted by $x=\left\{c_{1}(t), c_{2}(t), l_{F}(t), l_{I}(t), h(t), M(t), B(t)\right\}_{t=0}^{\infty}$, and the price system is denoted by $q=\left\{p(t), R(t), w_{F}(t), w_{I}(t)\right\}_{t=0}^{\infty}$, and government policy is $\pi=$ $\{\tau(t)\}_{t=0}^{\infty}$.

Definition 1. A competitive equilibrium is a government policy, $\pi$, a price system, $q$, and an allocation, $x$, such that

\footnotetext{
${ }^{7}$ Note that this function has constant average and marginal costs.
} 
1. given $\pi$ and $q$, the allocation $x$ solves the representative consumer's utility maximization problem (3).

2. given $\pi$ and $q$, the government's budget constraint (5) is satisfied for all $t$.

\section{The Ramsey Problem}

A Ramsey equilibrium is an optimal tax equilibrium where the government sets the tax policy before consumers make their consumption and labor decisions. The objective of the government is to choose the tax policy that would induce the highest possible utility for the consumers.

Definition 2. A Ramsey equilibrium is an allocation $x$ for the consumer and a government policy $\pi$ such that the government policy $\pi$ solves the problem:

$$
\max _{\left\{c_{1}(t), c_{2}(t), h(t)\right\}_{t=0}^{\infty}} \sum_{t=0}^{\infty} \beta^{t} U\left(c_{1}(t), c_{2}(t), h(t)\right)
$$

subject to the constraint that there exists $\{M(t), B(t), \tau(t)\}_{t=0}^{\infty}$ such that given $\pi=\{\tau(t)\}_{t=0}^{\infty}$, $x=\left\{c_{1}(t), c_{2}(t), l_{F}(t), l_{I}(t), h(t), M(t), B(t)\right\}_{t=0}^{\infty}$ is a competitive equilibrium allocation.

Proposition 1. [Ramsey Allocation] The consumption and labor allocations in a competitive equilibrium satisfy:

$$
\begin{gathered}
c_{1}(t)+c_{2}(t)+g(t)+(1-\kappa) l_{F}(t) Y_{l_{F}}(t)\left[1-\left(\frac{U_{h}(t)}{U_{c_{2}}(t)}\right) \frac{1}{Y_{l_{F}}(t)}\right]=Y\left(l_{F}(t), l_{I}(t)\right) \\
U_{c_{1}}(t) \geq U_{c_{2}}(t) \\
\sum_{t=0}^{\infty} \beta^{t}\left[c_{1}(t) U_{c_{1}}(t)+c_{2}(t) U_{c_{2}}(t)-(1-h(t)) U_{h}(t)\right]=0 \\
c_{1}(t), c_{2}(t), l_{F}(t), l_{I}(t), h(t) \geq 0 \\
1-\left(\frac{U_{h}(t)}{U_{c_{2}}(t)}\right) \frac{1}{Y_{l_{F}}(t)} \geq 0
\end{gathered}
$$

where

$$
h(t)=1-l_{F}(t)-l_{I}(t)
$$

Furthermore, the allocations that satisfy the above equations can be decentralized as a competitive equilibrium. 
Proof. : In the Appendix.

Constraint (7) resembles a feasibility constraint that has taken into account the first order conditions of the consumer's problem. Constraint (8) guarantees that the gross nominal interest rate is not less than 1 so that both government bonds and fiat money are held by the consumer in the equilibrium. Constraint (9) is the implementability constraint and is obtained by adding the consumer's budget constraints for each period and using the first order conditions of his utility maximization problem. And constraint (11) ensures that the labor income taxes are non-negative - otherwise the tax collection cost would lose its meaning.

Therefore the Ramsey Problem is to choose consumption and labor allocations that maximize the consumer's lifetime utility (1) subject to (7)-(12).

When the taxes are not costly to collect, i.e. $\kappa=1$, and when the informal labor is not an input of the production function, then the model boils down to the corresponding one in Chari and Kehoe (1999), where the Friedman Rule is optimal.

\section{Quantitative Results}

To analyze the quantitative implications of the model, functional forms for utility and production functions are assumed and the Ramsey Problem is rewritten in this section. I consider the steady state where the government's consumption expenditures, $g(t)$, are constant at level $g$, and solve for the optimal steady state interest rate in terms of the preference and production parameters.

Let the utility function be a CES function

$$
U\left(c_{1}(t), c_{2}(t), h(t)\right)=(1-\eta) \frac{1}{v} \log \left[(1-\sigma)\left(c_{1}(t)\right)^{v}+\sigma\left(c_{2}(t)\right)^{v}\right]+\eta \log [h(t)]
$$

And let the aggregate production function $\mathrm{be}^{8}$

$$
Y\left(l_{F}(t), l_{I}(t)\right)=\left(\alpha\left(l_{I}(t)\right)^{\rho}+(1-\alpha)\left(l_{F}(t)\right)^{\rho}\right)^{\frac{1}{\rho}}
$$

\footnotetext{
${ }^{8}$ Note that the elasticity of substitution between formal and informal labor is equal to $\frac{1}{1-\rho}$.
} 
Corollary 1. For an economy with utility function (13) and production function (14) the Ramsey Problem is to choose consumption and labor allocations that solve the optimization problem:

$$
\begin{array}{ll}
\max & \sum_{t} \beta^{t}\left[(1-\eta) \frac{1}{v} \log \left[(1-\sigma)\left(c_{1}(t)\right)^{v}+\sigma\left(c_{2}(t)\right)^{v}\right]+\eta \log \left[1-l_{F}(t)-l_{I}(t)\right]\right] \\
\text { s.t. } & c_{1}(t)+c_{2}(t)+g(t)+(1-\kappa) l_{F}(t) \otimes \\
& \otimes\left[Y_{l_{F}}(t)-\frac{\eta}{(1-\eta) \sigma} \frac{(1-\sigma)\left(c_{1}(t)\right)^{v}+\sigma\left(c_{2}(t)\right)^{v}}{\left(1-l_{F}(t)-l_{I}(t)\right)\left(c_{2}(t)\right)^{1-v}}\right]=Y\left(l_{I}(t), l_{F}(t)\right) \\
& (1-\sigma)\left(c_{1}(t)\right)^{v-1} \geq \sigma\left(c_{2}(t)\right)^{v-1} \\
& \sum_{t} \beta^{t}\left[(1-\eta)-\eta \frac{l_{F}(t)+l_{I}(t)}{1-l_{F}(t)-l_{I}(t)}\right]=0 \\
& Y_{l_{F}}(t)-\frac{\eta}{(1-\eta) \sigma} \frac{(1-\sigma)\left(c_{1}(t)\right)^{v}+\sigma\left(c_{2}(t)\right)^{v}}{\left(1-l_{F}(t)-l_{I}(t)\right)\left(c_{2}(t)\right)^{1-v} \geq 0} \\
& c_{1}(t), c_{2}(t), l_{F}(t), l_{I}(t) \geq 0
\end{array}
$$

where

$$
Y\left(l_{F}(t), l_{I}(t)\right)=\left(\alpha\left(l_{I}(t)\right)^{\rho}+(1-\alpha)\left(l_{F}(t)\right)^{\rho}\right)^{\frac{1}{\rho}}
$$

Proof. : Follows from Proposition 1.

I assume that the government's consumption expenditures, $g(t)$, are constant at level $g$ for each period, and then consider the steady state solution to the Ramsey problem where the real variables are constant over time.

The parameters of the baseline economy are chosen to match the US macroeconomic data. Table 5 lists the baseline parameters. A period is assumed to be a quarter. Thus I set the period discount factor to be $\beta=0.99$. In the steady state the implementability constraint implies that $h=\eta$. Hence $\eta$ is chosen to be 0.75 so that one quarter of the representative consumer's time is allocated to work — which is roughly 40 hours a week. The preference parameters $\sigma$ and $v$ for the US economy are estimated by Chari, Christiano, and Kehoe (1991) using the demand function for real balances based on quarterly data. In the baseline economy I use the values these authors report which are consistent with the existing money demand literature. 
Lemieux, Fortin, and Frechette (1994) estimate the elasticity of substitution between formal and informal labor in Canada. Assuming that the elasticity of substitution between formal and informal labor is about the same in the US, I use their estimate in my baseline economy. Therefore $\rho$ is assumed to be 0.71 .

As given in Table 2, between 1976 and 2000 the size of the IRS budget on average was $0.5 \%$ of the total tax revenue. Therefore I assume the efficiency parameter of the tax collection system, $\kappa$, to be 0.995 in the baseline economy.

The production parameter $\alpha$ and the government expenditures parameter $g$ are chosen so that the size of the informal sector corresponds to $10 \%$ and the size of the government corresponds to $20 \%$ of the formal output respectively at the resulting Ramsey equilibrium. Therefore $\alpha$ is set equal to 0.305 which yields $\frac{w_{I} l_{I}}{w_{F} l_{F}}=0.1$, and $g$ is set equal to 0.0276 which gives $\frac{g+(1-\kappa) \tau w_{F} l_{F}}{w_{F} l_{F}}=0.2$ at the Ramsey equilibrium ${ }^{9}$.

For the baseline economy I find the optimal quarterly interest rate to be $1.97 \%$. Therefore the optimal annual interest rate is $8.12 \%$, and the annual inflation rate ${ }^{10}$ is $3.86 \%$.

I also compute the annual seigniorage revenue for the baseline economy. At the Ramsey equilibrium the seigniorage revenue has a $0.50 \%$ share of formal output or a $2.53 \%$ share of government consumption expenditures. Note that these numbers are close to, but little higher than, the actual ones.

Without tax collection costs, i.e. $\kappa=1$, the model predicts the optimal annual interest rate to be $7.65 \%$. Hence roughly a 0.5 percent difference in the optimal interest rate is due to assuming that the unit cost of tax collection is 0.005 .

The following figures are based on the baseline economy parameters and illustrate the relationship between the parameters and the optimal interest rate. Figure 3 shows how the optimal annual interest rate responds to changes in the size of the informal sector. Note that in this model the size of the informal sector as a share of formal output is determined endogeneously in equilibrium. I observe that as $\alpha$ increases, both the size of the informal

\footnotetext{
${ }^{9}$ Since the production function is constant returns-to-scale, the income - and thus the output — of the formal and informal sectors can be approximated by the formal and informal labor wage shares, respectively.

${ }^{10}$ Consumer's first order condition in the steady state implies that $1=\beta R \frac{p(t)}{p(t+1)}$.
} 
sector and the Ramsey interest rate increase.

The negative relationship between the efficiency of the tax system and the Ramsey interest rate is shown in Figure 4. Where the efficiency of the tax system is low, the optimal interest rate is significantly high.

Figure 5 demonstrates that the optimal interest rate increases as the size of the government increases. Again in this model the size of the government is determined endogeneously in the equilibrium. The figure shows that as the level of government consumption expenditures, $g$, increases, both the size of the government and the optimal interest rate increase.

Higher $\rho$ signifies higher substitutability between informal and formal labor. Intuitively, therefore, a higher $\rho$ means higher optimal interest rates for a given value of government consumption expenditures, $g$, because the consumers will shift to the informal sector more rapidly when they see higher tax rates, and the government will need to rely on seigniorage revenue more. Figure 6 shows the high sensitivity of the optimal interest rates to the choice of $\rho$. For a country where it is easy to switch from formal sector to informal sector the optimal interest rate will be much higher.

Then, for each country listed in Table 1, I find the optimal interest rate by varying the parameter values of $g$ and $\alpha$ in the estimations so that the resulting Ramsey equilibrium numbers match the actual sizes of the government and of the informal sector, respectively. I also use the country specific $\kappa$ value whenever available - if no estimate for $\kappa$ was reported in Table 3, $\kappa$ is assumed to be equal to 0.995 as in the US. Table 6 documents the Ramsey interest rates and the actual interest rates for the whole sample and Figure 7 charts the findings. For some of the countries in the sample, the estimated interest rates are very close to the actual levels (e.g. Australia, India and Spain), and for some countries the actual and the estimated interest rates differ widely (e.g. Chile, Denmark, Malaysia and Peru).

In order to see how much of the cross-country variation in monetary policy the model can explain, actual interest rates are projected on the Ramsey interest rates. Table 7 shows the regression results with the standard errors given in parentheses. The adjusted $\mathrm{R}^{2}$ in the complete sample is only 0.202 and most of the model's explanatory power comes from one data point, namely Israel. Excluding that data point from the sample, the adjusted $\mathrm{R}^{2}$ 
drops to 0.010. However, in both regressions the slope coefficient is significantly different from zero and the hypothesis that it is different from 1 cannot be rejected for any reasonable confidence level.

However, in the small subsample of the countries for which the tax collection costs could be directly estimated, the model performs fairly well in explaining the variation in nominal interest rates. Those countries are denoted with a square in Figure 7. An interesting observation is that the interest rate is overestimated in Asian countries, whereas it is underestimated in Latin American countries. One possible explanation for this pattern could be that the elasticity of substitution between formal and informal sectors are actually different from country to country. If - for example, in Latin American countries - this parameter is higher than the benchmark value, then the optimal interest rates would be closer to observed ones in those countries as well. However, with the available data, the model can only partly explain the variation in monetary policy across countries. Other possible explanations for this result are that some other element was missing in this model or that these governments were not optimally responding to the factors considered here.

\section{Conclusion}

In this essay I have tried to systematically account for the differences in monetary policy across countries. In particular, I have asked to what extent the variation in nominal interest rates can be explained as being due to governments' optimal response to economic conditions such as tax collection costs, presence of an informal sector and government consumption needs. Using a cash-credit model with these factors, I have estimated optimal interest rates for a variety of countries and compared my estimates with actual interest rates.

I find that for some reasonable parameter values the model implies quite high optimal interest rates, and for some countries the estimated and actual interest rates are very close to each other. In the small sample of countries with available tax collection cost data, the model performs fairly well. However, in the whole sample it overestimates the interest rate for the Asian countries, and underestimates it for the Latin American countries. I also find 
that the elasticity of substitution parameter between informal and formal sectors plays a crucial role in the estimations. The model's explanatory power would further improve if country specific estimates of this parameter could be used. However, based on the available data, I conjecture that optimality considerations seem to account for a small fraction of the variation in nominal interest rates in these countries, or that these governments were not optimally responding to the elements considered in the model here. It is still possible that other factors, such as politico-economic ones, can be more responsible for the cross-country variation in monetary policy. Further research needs to be done to find and analyze these missing elements. 


\section{Appendix}

\section{Proof of the Proposition 1 [Ramsey Allocation]:}

This proof is similar to the corresponding one in Chari, Christiano and Kehoe (1991). First I need to show that these constraints are all satisfied in a competitive equilibrium.

At a competitive equilibrium, the allocation $x$ must satisfy the period budget constraint of both the government and the consumer:

$$
\begin{aligned}
R(t) B(t)+p(t) g(t)= & M(t+1)-M(t)+B(t+1) \\
& +\kappa p(t) \tau(t) l_{F}(t) w_{F}(t) \\
M(t+1)+B(t+1)+p(t) c_{1}(t)+p(t) c_{2}(t)= & R(t) B(t)+M(t)+p(t) l_{I}(t) w_{I}(t) \\
& +p(t)[1-\tau(t)] l_{F}(t) w_{F}(t)
\end{aligned}
$$

Adding these two equations and then dividing by $p(t)$, I get

$$
c_{1}(t)+c_{2}(t)+g(t)+(1-\kappa) \tau(t) l_{F}(t) w_{F}(t)=l_{F}(t) w_{F}(t)+l_{I}(t) w_{I}(t)
$$

From the first order conditions of the consumer's problem (3), I also have $\tau(t)=1-$ $\frac{U_{h}(t)}{U_{c_{2}}(t)} \frac{1}{w_{F}(t)}$. Using this condition and the fact that the production function is constant returns to scale ${ }^{11}$ in the above equation I obtain (7).

Another first order condition of the consumer's problem (3) is that $\frac{U_{c_{1}}(t)}{U_{c_{2}}(t)}=R(t)$. Since consumers would not be willing to hold bonds if their rate of return was strictly less than the rate of return on fiat money, it must be the case that $R(t) \geq 1$. Thus $U_{c_{1}}(t) \geq U_{c_{2}}(t)$, and (8) is satisfied as well.

In the literature constraint (9) is commonly called the implementability constraint. To prove that it holds at a competitive equilibrium, I multiply the budget constraints of the consumer by their Lagrange multipliers for each period, take their infinite sum and use the first order conditions of the consumer's problem to simplify the resulting expression. The procedure is straightforward yet tedious and is left out here.

Condition (10) simply lists the non-negativity constraints for the labor supply and consumption; they all have to be satisfied in a competitive equilibrium. Finally, condition (11)

\footnotetext{
${ }^{11}$ So that $l_{F}(t) w_{F}(t)+l_{I}(t) w_{I}(t)=Y\left(l_{F}(t), l_{I}(t)\right)$ holds.
} 
guarantees that the tax rate is non-negative - otherwise tax collection costs would lose their meaning.

Next, I need to show that these equations completely characterize a competitive equilibrium. In order to prove this, I define the tax rate in each period $t$ to be $\tau(t)=1-\frac{U_{h}(t)}{U_{c_{2}}(t)} \frac{1}{w_{F}(t)}$. Then I construct the interest rate as $R(t)=\frac{U_{c_{1}}(t)}{U_{c_{2}}(t)}$.

Note that the price level remains indeterminate. But I can define all variables in the economy in real terms. Because of the cash-in-advance constraint, real money holdings will be equal to the consumption of the cash good, $\frac{M(t)}{p(t)}=c_{1}(t)$.

Finally, real bond holdings can be constructed using the following equation, which can be obtained by a method similar to the one used to derive the implementability constraint:

$$
\frac{B(r)}{p(r)}=\frac{1}{R(r) U_{c_{2}}(r)}\left[\sum_{t=r}^{\infty} \beta^{t-r}\left[c_{1}(t) U_{c_{1}}(t)+c_{2}(t) U_{c_{2}}(t)-(1-h(t)) U_{h}(t)\right]-c_{1}(r) U_{c_{1}}(r)\right]
$$

This completes the construction of the competitive equilibrium. 


\section{References}

Tiago Cavalcanti and Anne Villamil. The optimal inflation tax and structural reform. Macroeconomic Dynamics, 7(3):333-362, June 2003.

V.V. Chari, Lawrence J. Christiano, and Patrick Kehoe. Optimal fiscal and monetary policy: Some recent results. Journal of Money, Credit and Banking, 23(3):519-539, August 1991.

V.V. Chari, Lawrence J. Christiano, and Patrick Kehoe. Optimality of the friedman rule in economies with distorting taxes. Journal of Monetary Economics, 37:203-223, April 1996.

V.V. Chari and Patrick Kehoe. Optimal fiscal and monetary policy. In John Taylor and Michael Woodford, editors, Handbook of Macroeconomics, volume 1c. Elsevier, 1999.

Reid W. Click. Seigniorage in a cross-section of countries. Journal of Money, Credit and Banking, 30(2):154-171, May 1998.

Isabel Correia and Pedro Teles. The optimal inflation tax. Review of Economic Dynamics, 2(2):325-346, April 1999.

Alex Cukierman, Sebastian Edwards, and Guido Tabelini. Seigniorage and political instability. The American Economic Review, 82(3):537-555, June 1992.

Fiorella de Fiore. The optimal inflation tax when taxes are costly to collect. European Central Bank Working Paper, 38, November 2000.

Milton Friedman. The optimum quantity of money. In The Optimum Quantity of Money and other Essays. Aldine, Chicago, 1969.

Alan Heston, Robert Summers, and Bettina Aten. Penn world table version 6.1. Center for International Comparisons at the University of Pennsylvania (CICUP), 2002.

Simon Johnson, Daniel Kaufmann, and Pablo Zoido-Lobatón. Regulatory discretion and the unofficial economy. The American Economic Review, 88(2):387-392, May 1998.

John Maynard Keynes. Monetary Reform. Hartcourt, Brace and Company, New York, 1924. 
Tatyana Koreshkova. Accounting for inflation rates in developing countries. Manuscript, University of Western Ontario, 2001.

Thomas Lemieux, Bernard Fortin, and Pierre Frechette. The effects of taxes on labor supply in the underground economy. The American Economic Review, 84(1):231-254, March 1994.

Robert E. Lucas, Jr. and Nancy L. Stokey. Optimal fiscal and monetary policy in an economy without capital. Journal of Monetary Economics, 12(1):55-93, July 1983.

Juan Pablo Nicolini. Tax evasion and the optimal inflation tax. Journal of Development Economics, 55(1):215-232, February 1998.

Fethi Ögünç and Gökhan Yılmaz. Estimating the underground economy in Turkey. The Central Bank of the Republic of Turkey Discussion Paper, 2000.

Frank Ramsey. A contribution to the theory of taxation. The Economic Journal, 37:47-61, March 1927.

Friedrich Schneider. The size and development of the shadow economies of 22 transition and 21 OECD countries. Institute for the Study of Labor (IZA) Discussion Paper, 514, 2002.

Friedrich Schneider and Dominik Enste. Shadow economies: Size, causes, and consequences. Journal of Economic Literature, 38(1):77-114, March 2000.

Michael Stavrianos and Arnold Greenland. Design and development of the wage and investment compliance burden model. IRS Research Conference Paper, August 2002.

Carlos Végh. Government spending and inflationary finance: A public finance approach. International Monetary Fund Staff Paper, 36, 1989.

Ann Witte. The nature and extent of recorded activity: A survey concentrating on US research. In Sergio Alessandrini and Bruno Dallago, editors, The Unofficial Economy: Consequences and Perspectives in Different Economic Systems. Ashgate Publishing Company, 1987. 
Table 1: Interest Rates and Seigniorage Revenues (1976-2000)

\begin{tabular}{lrrr}
\hline \hline Country & Interest Rate & Seigniorage Revenue \\
& $(\%)$ & $(\%)$ & Seigniorage Revenue \\
& & $(\Delta M / G D P)$ \\
\hline Australia & 11.54 & 1.61 & 0.36 \\
Bolivia* & 54.03 & 13.81 & 3.14 \\
Canada & 8.86 & 1.08 & 0.25 \\
Chile* & 39.86 & 28.67 & 7.53 \\
Colombia & 31.78 & 5.99 & 1.99 \\
Denmark & 7.20 & 2.04 & 0.62 \\
Egypt & 12.63 & 11.82 & 4.80 \\
Greece & 17.66 & 4.54 & 1.35 \\
India & 10.04 & 12.57 & 1.89 \\
Israel* & 113.47 & 16.49 & 11.62 \\
Italy & 12.22 & 1.73 & 0.59 \\
Malaysia & 5.03 & 8.73 & 2.07 \\
Mexico* & 30.80 & 11.48 & 2.90 \\
Norway & 9.11 & 1.09 & 0.38 \\
Peru & 103.97 & 29.29 & 4.78 \\
Portugal & 14.69 & 2.18 & 0.85 \\
South Korea & 7.56 & 6.26 & 0.92 \\
Spain & 10.80 & 4.84 & 0.96 \\
Sweden & 7.40 & 1.03 & 0.43 \\
Switzerland & 3.31 & 1.84 & 0.19 \\
Turkey & 43.17 & 15.18 & 3.14 \\
United States & 6.67 & 1.26 & 0.39 \\
Uruguay* & 88.10 & 20.14 & 4.95 \\
\hline & & & \\
\hline
\end{tabular}

Source: International Monetary Fund International Financial Statistics.

$\S$ : 25-year averages of end of period discount rates, series 60 of IMF IFS. For countries marked with an asteriks the lending rate, series 60P, was used instead to obtain the longest data.

$\dagger$ : 25-year averages of change in reserve money - government consumption expenditures ratio (series 14 and 82, respectively).

$\ddagger$ : 25-year averages of change in reserve money - nominal GDP ratio (series 14 and 99b, respectively). 
Table 2: Tax Collection Costs for the US (1976-2000)

\begin{tabular}{crrc}
\hline \hline Fiscal year & Operating Costs ${ }^{\S}$ & Gross Collections $^{\dagger}$ & Cost of Collecting $\$ 100^{\ddagger}$ \\
\hline 1976 & $1,667,311,689$ & $302,519,791,922$ & 0.55 \\
1977 & $1,790,588,738$ & $358,139,416,730$ & 0.50 \\
1978 & $1,962,129,287$ & $399,776,389,362$ & 0.49 \\
1979 & $2,116,166,276$ & $460,412,185,013$ & 0.46 \\
1980 & $2,280,838,622$ & $519,375,273,361$ & 0.44 \\
1981 & $2,465,468,704$ & $606,799,103,000$ & 0.41 \\
1982 & $2,626,338,036$ & $632,240,505,595$ & 0.42 \\
1983 & $2,968,525,840$ & $627,246,792,581$ & 0.47 \\
1984 & $3,279,067,495$ & $680,475,229,453$ & 0.48 \\
1985 & $3,600,952,523$ & $742,871,541,283$ & 0.48 \\
1986 & $3,841,983,050$ & $782,251,812,225$ & 0.49 \\
1987 & $4,365,816,254$ & $886,290,589,996$ & 0.49 \\
1988 & $5,035,543,000$ & $935,106,594,000$ & 0.54 \\
1989 & $5,198,546,063$ & $1,013,322,133,000$ & 0.51 \\
1990 & $5,440,417,630$ & $1,056,365,651,631$ & 0.52 \\
1991 & $6,097,627,226$ & $1,086,851,401,315$ & 0.56 \\
1992 & $6,536,336,443$ & $1,120,799,558,292$ & 0.58 \\
1993 & $7,077,985,000$ & $1,176,685,625,083$ & 0.60 \\
1994 & $7,245,344,000$ & $1,276,466,775,871$ & 0.57 \\
1995 & $7,389,692,000$ & $1,375,731,835,498$ & 0.54 \\
1996 & $7,240,221,000$ & $1,486,546,674,000$ & 0.49 \\
1997 & $7,163,541,000$ & $1,623,272,071,000$ & 0.44 \\
1998 & $7,564,661,000$ & $1,769,408,739,000$ & 0.43 \\
1999 & $8,269,387,000$ & $1,904,151,888,000$ & 0.43 \\
2000 & $8,258,423,000$ & $2,096,916,925,000$ & 0.39 \\
\hline
\end{tabular}

Source: IRS Data Book, Fiscal Year 2001, Publication 55b.

$\S$ : In US dollars. Represents actual IRS operating costs, exclusive of reimbursements received from other Federal agencies for services performed.

${ }^{\dagger}$ : In US dollars. Starting with Fiscal Year 1988, gross collections exclude alcohol and tobacco taxes and, starting with the second quarter of Fiscal Year 1991, exclude taxes on firearms, when responsibility for all these taxes was transferred to the Bureau of Alcohol, Tobacco and Firearms. Also, starting with Fiscal Year 1993, gross collections exclude foreign treaty money and arbitrage rebates.

$\ddagger$ : In US dollars. Ratio of column 2 to column 3 times 100 . 
Table 3: Tax Collection Costs for Some Countries

\begin{tabular}{lccc}
\hline \hline Country & $\begin{array}{c}\text { Total Tax } \\
\text { Revenue }^{\dagger}\end{array}$ & $\begin{array}{c}\text { Budget of Tax } \\
\text { Collection Agency }^{\dagger}\end{array}$ & $\begin{array}{c}\text { Efficiency of the } \\
\text { Tax System }^{\ddagger}\end{array}$ \\
\hline Australia & 149,023 & 4,613 & 0.969 \\
Canada & 169,676 & 4,561 & 0.973 \\
Israel & 124,295 & 1,246 & 0.989 \\
Norway & 498,504 & 3,838 & 0.992 \\
Turkey & $2,244,094,000$ & $308,629,000$ & 0.862 \\
US & $1,486,547$ & 7,241 & 0.995 \\
\hline
\end{tabular}

Sources: Department of Finance and Administration of Australia (fiscal year 1999-2000); Canada Customs and Revenue Agency (fiscal year 2000-2001); Ministry of Finance of Israel (fiscal year 1999); Ministry of Finance of Norway (fiscal year 1999); Central Bank of the Republic of Turkey, and Ministry of Finance of Turkey (fiscal year 1996); US Internal Revenue Services (fiscal year 1996).

$\dagger$ : The numbers are in millions of national currency of the listed countries.

$\ddagger$ : One minus the ratio of the budget of tax collection agency to total tax revenue. 
Table 4: The Size of the Government and the Size of the Informal Sector

\begin{tabular}{lrr}
\hline \hline Country & $\begin{array}{r}\text { Size of the } \\
\text { Government } \\
\text { (\% of GDP) }\end{array}$ & $\begin{array}{r}\text { Size of the } \\
\text { Informal Sector } \\
\text { (\% of GDP) }\end{array}$ \\
\hline Australia & 19.16 & $10.1-15.3$ \\
Bolivia & 12.77 & 65.6 \\
Canada & 19.82 & $10.0-13.5$ \\
Chile & 11.97 & $18.2-37.0$ \\
Colombia & 12.22 & $25-35.1$ \\
Denmark & 26.01 & $9.4-16.9$ \\
Egypt & 14.02 & 68.0 \\
Greece & 16.24 & $21.8-27.2$ \\
India & 10.89 & 22.4 \\
Israel & 33.10 & 29.0 \\
Italy & 18.17 & $19.6-24.0$ \\
Malaysia & 14.10 & 39.0 \\
Mexico & 10.09 & $27.1-49.0$ \\
Norway & 20.06 & $5.9-16.7$ \\
Peru & 9.91 & $44-57.4$ \\
Portugal & 16.49 & $15.6-16.8$ \\
South Korea & 10.53 & $20.3-38.0$ \\
Spain & 14.90 & $16.1-22.9$ \\
Sweden & 27.38 & $10.6-17.0$ \\
Switzerland & 14.23 & $6.7-10.2$ \\
Turkey & 11.46 & $15.7-46.2$ \\
United States & 19.75 & $6.7-13.9$ \\
Uruguay & 12.91 & 35.2 \\
\hline
\end{tabular}

Sources:

$\dagger$ : The size of the government is computed as the ratio of government consumption expenditures to domestic output produced by the formal sector, series $91 \mathrm{f}$ and $99 \mathrm{~b}$ of the International Monetary Fund IFS, respectively. The numbers reported here are averages over the period 1976-2000.

‡: Informal sector size estimates are ratios of output produced by informal sector to output produced by formal sector in a year during the period 1989-1993. A range indicates that at least two methods were applied in the estimations, reported in Schneider and Enste (2000) and Ögüüç and Yılmaz (2000). 
Table 5: Baseline Economy Parameters

\begin{tabular}{||c|c|c|c|c|c|c|c||}
\hline \hline \multicolumn{4}{|c|}{ Preferences } & \multicolumn{2}{c||}{ Production } & \multicolumn{2}{c||}{ Government } \\
\hline$\beta$ & $\eta$ & $\sigma$ & $v$ & $\rho$ & $\alpha$ & $\kappa$ & $g$ \\
\hline 0.99 & 0.75 & 0.57 & 0.83 & 0.71 & 0.305 & 0.995 & 0.0276 \\
\hline \hline
\end{tabular}

Table 6: Actual and Ramsey Annual Interest Rates

\begin{tabular}{lrr}
\hline \hline Country & Actual Interest Rate & Ramsey Interest Rate \\
& $(\%)$ & $(\%)$ \\
\hline Australia & 11.54 & 11.31 \\
Bolivia & 54.03 & 33.67 \\
Canada & 8.86 & 10.83 \\
Chile & 39.86 & 12.99 \\
Colombia & 31.78 & 14.43 \\
Denmark & 7.20 & 19.38 \\
Egypt & 12.63 & 40.27 \\
Greece & 17.66 & 17.30 \\
India & 10.04 & 9.50 \\
Israel & 113.47 & 42.90 \\
Italy & 12.22 & 18.13 \\
Malaysia & 5.03 & 22.63 \\
Mexico & 30.80 & 14.27 \\
Norway & 9.11 & 9.22 \\
Peru & 103.97 & 18.41 \\
Portugal & 14.69 & 11.83 \\
South Korea & 7.56 & 11.67 \\
Spain & 10.80 & 11.46 \\
Sweden & 7.40 & 22.32 \\
Switzerland & 3.31 & 5.44 \\
Turkey & 43.17 & 20.06 \\
United States & 6.67 & 8.12 \\
Uruguay & 88.10 & \\
\hline & & \\
\hline & & \\
& &
\end{tabular}

Source: IMF International Financial Statistics and author's estimates based on the model. 
Table 7: Regression Results

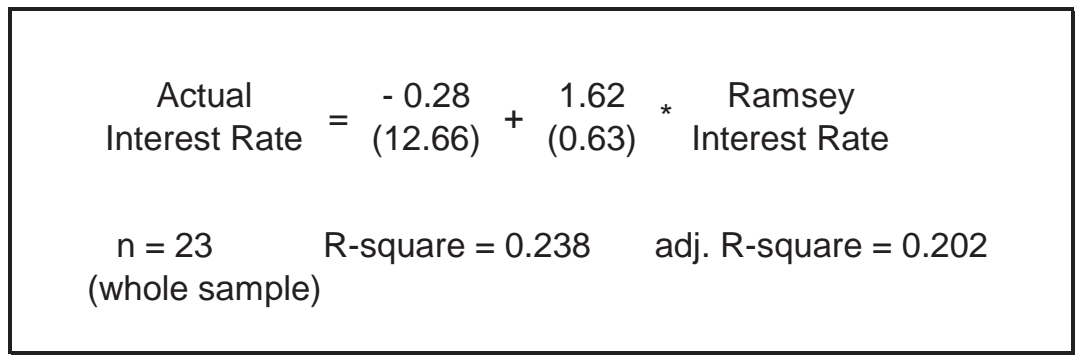

$\begin{gathered}\text { Actual } \\ \text { Interest Rate }\end{gathered}=\begin{gathered}11.35 \\ (13.12)\end{gathered}+\begin{gathered}0.79 \\ (0.72)\end{gathered}$
$\begin{gathered}\mathrm{n}=22 \quad \begin{array}{c}\text { Ramsey } \\ \text { Interest Rate }\end{array} \\ \text { (excluding Israel) }\end{gathered}$
R-square $=0.058 \quad$ adj. R-square $=0.010$

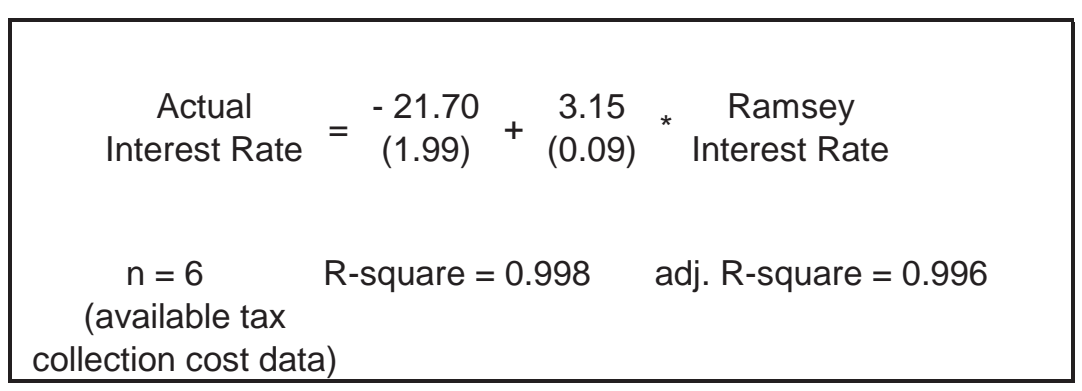


Figure 1: Size of the Government and Interest Rates

(Annual Averages over 1976-2000)

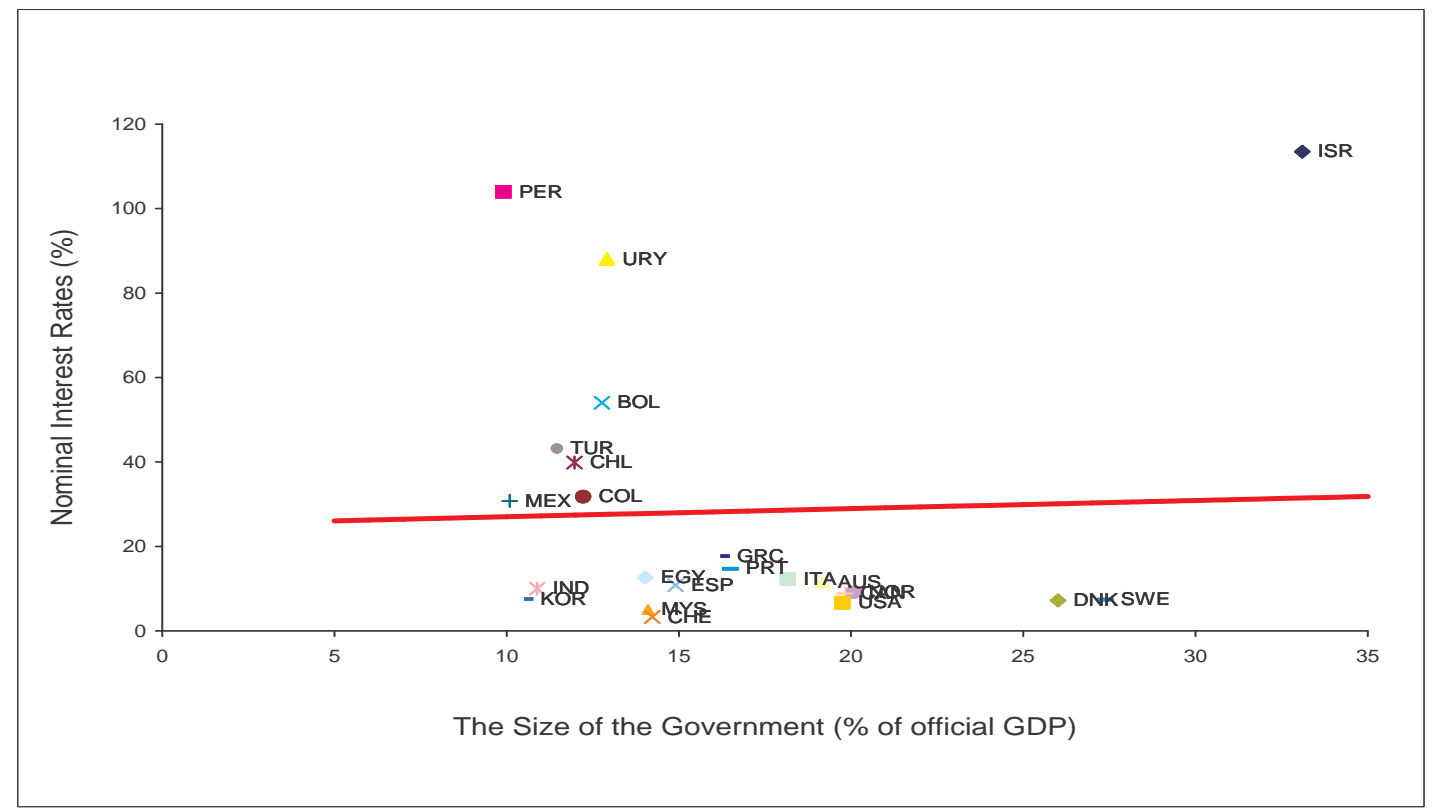

Figure 2: Size of the Informal Sector and Interest Rates

(Annual Averages over 1976-2000)

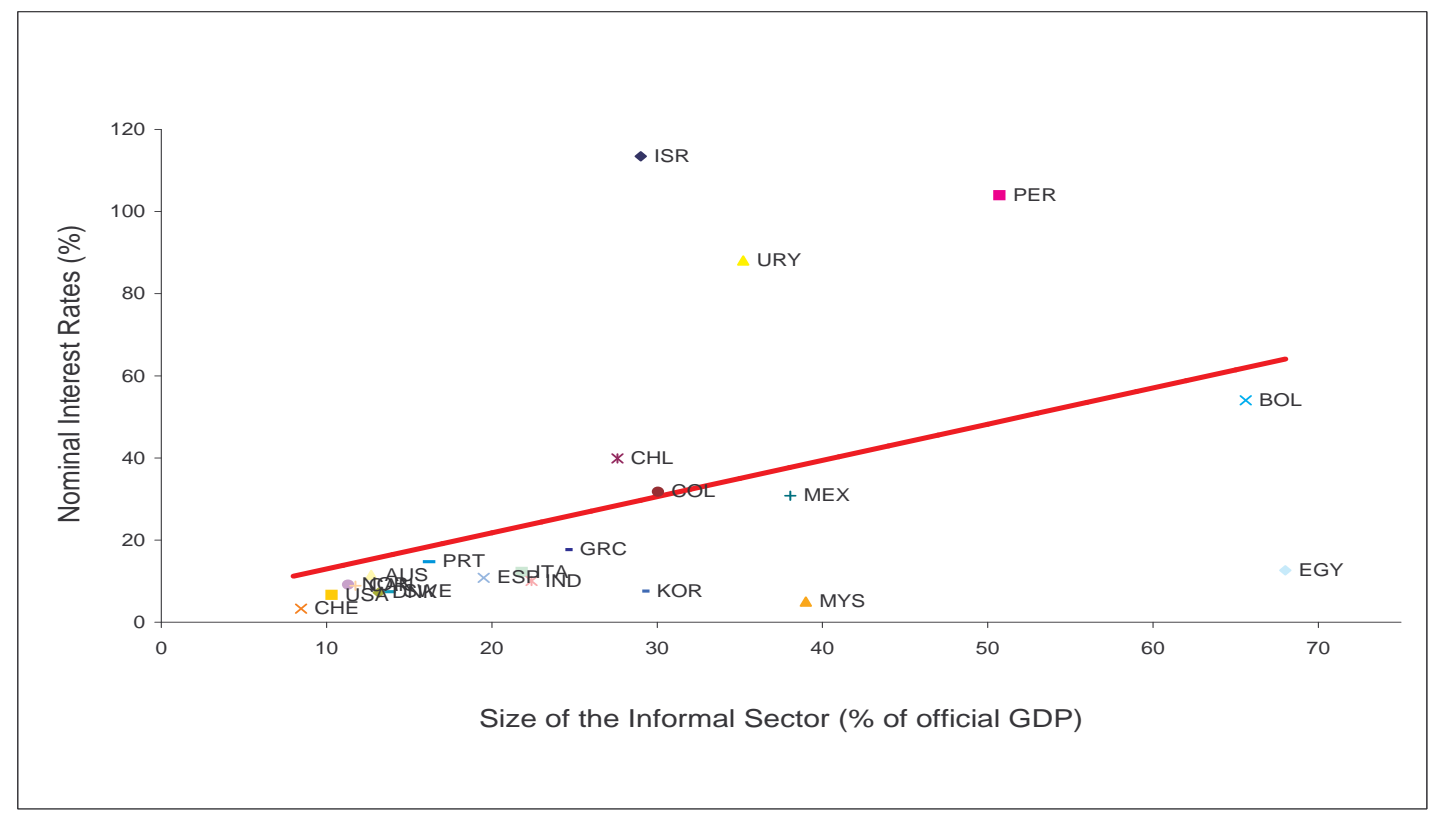


Figure 3: The Size of the Informal Sector and Ramsey Interest Rates

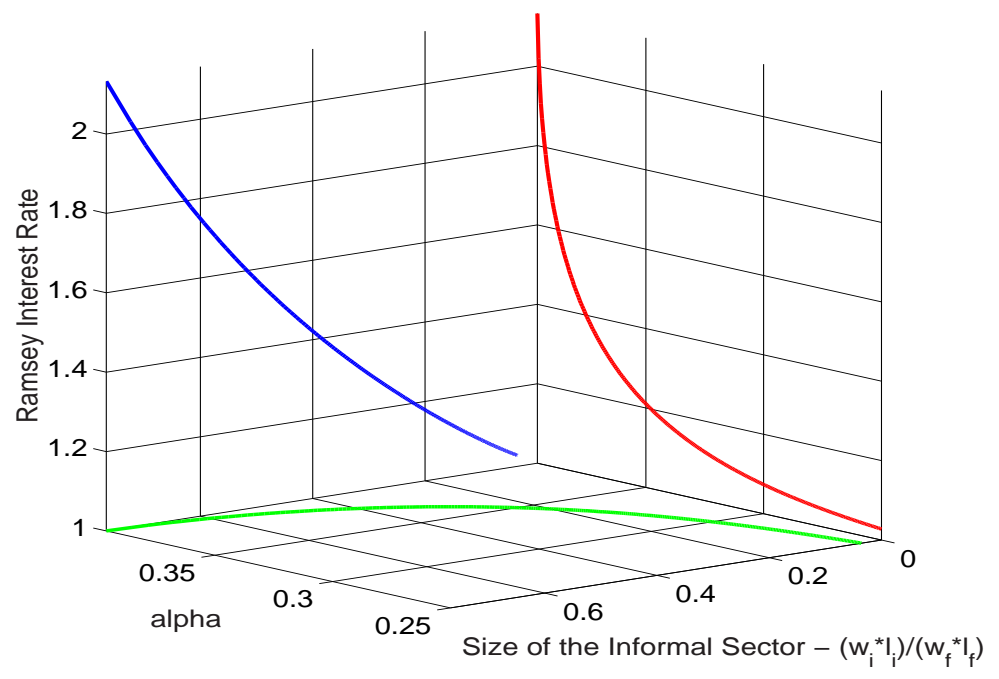

Figure 4: The Efficiency of the Tax System and Ramsey Interest Rates

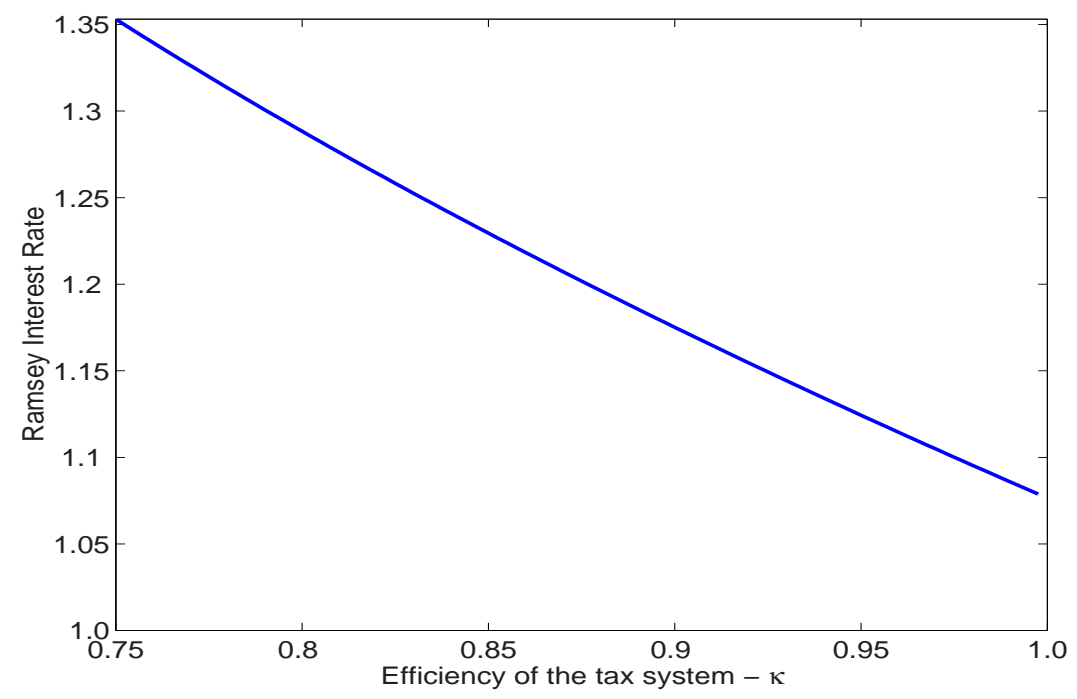


Figure 5: The Size of the Government and Ramsey Interest Rates

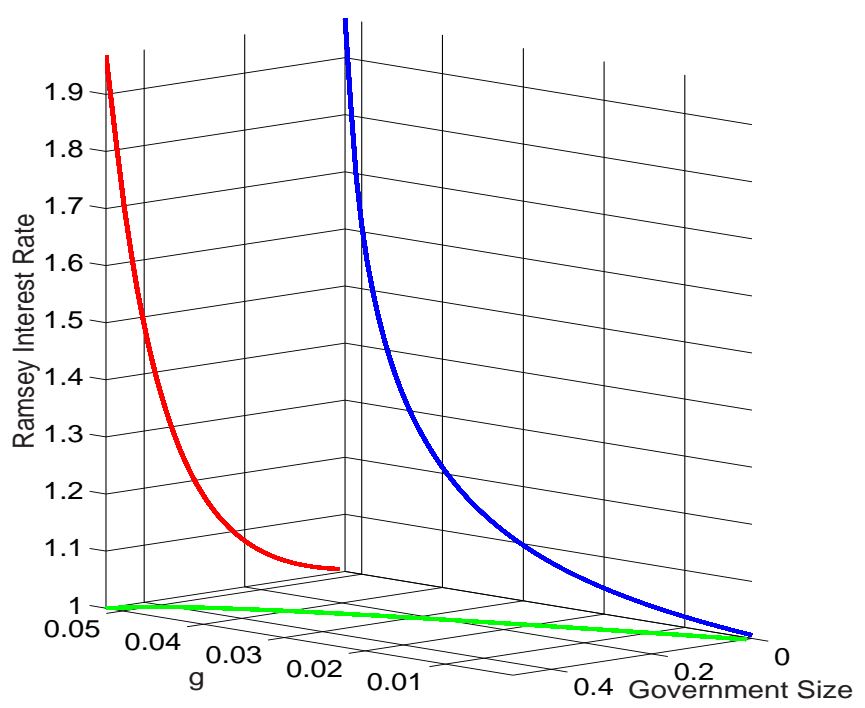

Figure 6: Sensitivity to the Elasticity of Substitution between Formal and Informal Labor

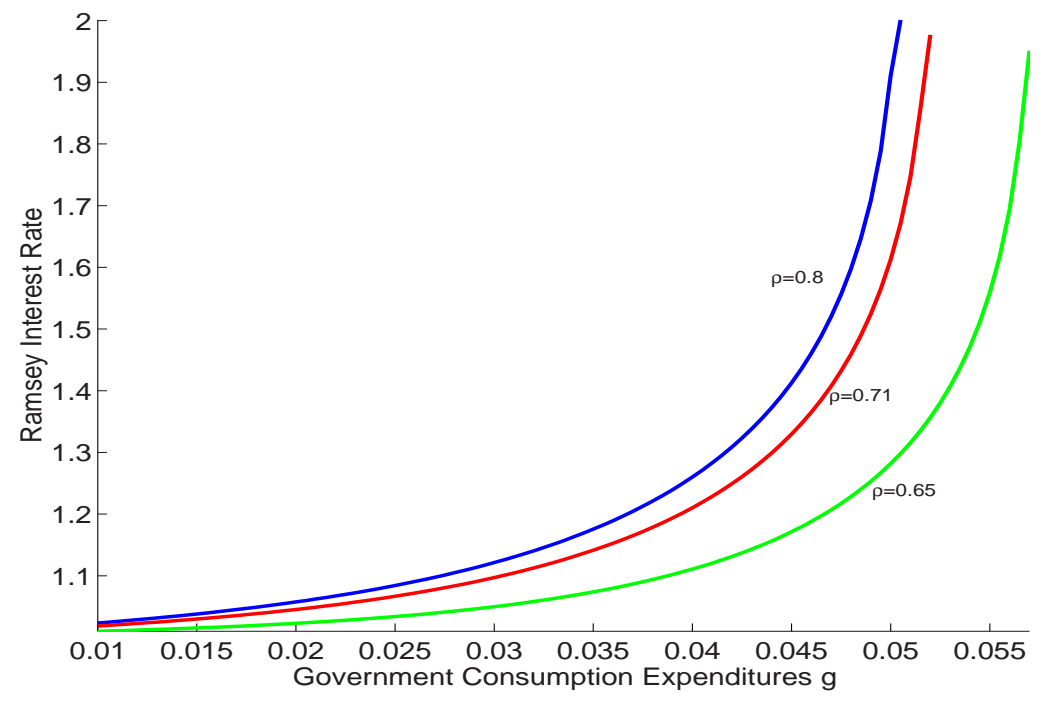


Figure 7: Actual and Ramsey Interest Rates

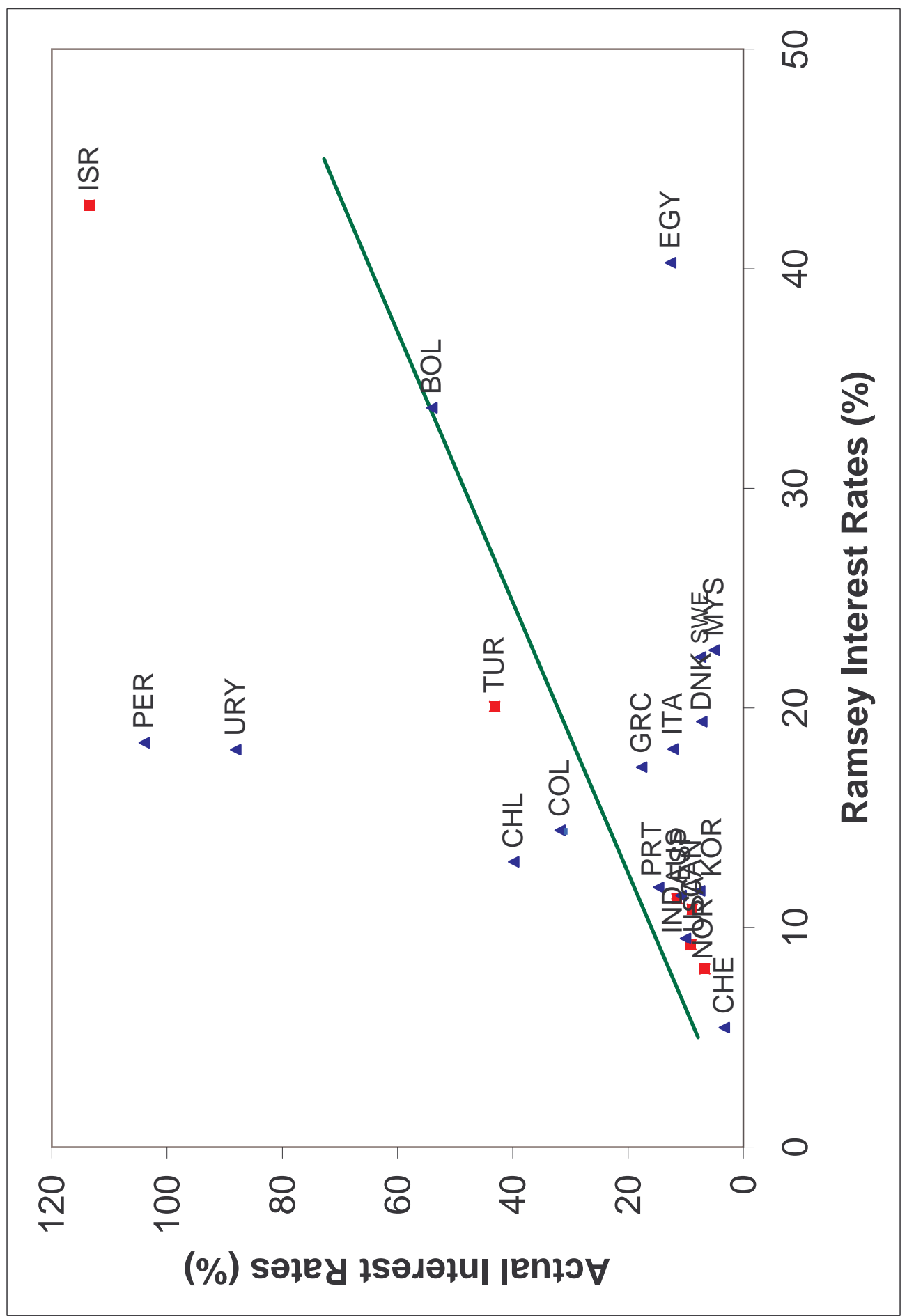

